\title{
Is the Spinal Instability Neoplastic Score Accurate and Reliable in Predicting Vertebral Compression Fractures for Spinal Metastasis? A Systematic Review and Qualita- tive Analysis
}

\author{
Chang-Hyun Lee, Jae Taek Hong, ${ }^{2}$ Sun-Ho Lee, ${ }^{3}$ Seong Yi, ${ }^{4}$ Moon-Jun Sohn, ${ }^{5}$ Sung Hwan Kim, ${ }^{6}$ Chun Kee Chung, ${ }^{1,7}$ \\ on behalf of Korean Spine Oncology Research Society \\ Department of Neurosurgery,' Seoul National University Hospital, Seoul National University College of Medicine, Seoul, Korea \\ Department of Neurosurgery, ${ }^{2}$ Eunpyeong St. Mary's Hospital, The Catholic University of Korea, Seoul, Korea \\ Department of Neurosurgery and Spine Center, ${ }^{3}$ Samsung Medical Center, Sungkyunkwan University School of Medicine, Seoul, Korea \\ Department of Neurosurgery, ${ }^{4}$ Severance Hospital, Yonsei University College of Medicine, Seoul, Korea \\ Department of Neurosurgery, ${ }^{5}$ Neuroscience \& Radiosurgery Hybrid Research Center, Inje University Ilsan Paik Hospital, Goyang, Korea \\ Department of Radiation Oncology, ${ }^{6}$ St. Vincent's Hospital, The Catholic University of Korea, Suwon, Korea \\ Department of Brain and Cognitive Sciences, ${ }^{7}$ Seoul National University College of Natural Sciences, Seoul, Korea
}

Spinal metastases can present with varying degrees of mechanical instability. The Spinal Instability Neoplastic Score (SINS) was developed as a tool to assess spinal neoplastic-related instability while helping to guide referrals among oncology specialists. Some previous papers suggested that the SINS was accurate and reliable, while others disagreed with this opinion. We performed a systematic review regarding the SINS to evaluate its accuracy and precision in predicting vertebral compression fractures (VCFs). The 21 included studies investigated a total of 2118 patients. Thirteen studies dealt with the accuracy of SINS to predict postradiotherapy VCFs, and eight dealt with the precision. Among 13 studies, 11 agreed that the SINS categories showed statistically significant accuracy in predicting VCF. Among eight studies, body collapse was effective for predicting VCFs in six studies, and alignment and bone lesion in two studies. Location has no statistical significance in predicting VCFs in any of the eight studies. The precision of SINS categories was substantial to excellent in six of eight studies. Among the six components of the SINS, the majority of the included studies reported that location showed near perfect agreement; body collapse, alignment, and posterolateral involvement showed moderate agreement; and bone lesion showed fair agreement. Bone lesion showed significant accuracy in predicting VCFs in half of eight studies, but displayed fair reliability in five of seven studies. Although location was indicated as having near perfect reliability, the component showed no accuracy for predicting VCFs in any of the studies and deleting or modifying the item needs to be considered. The SINS system may be accurate and reliable in predicting the occurrence of postradiotherapy VCFs for spinal metastasis. Some components seem to be substantially weak and need to be revised.

Key Words : Spine · Metastasis · Spinal neoplastic instability score · Fractures, Compression · Radiotherapy.

- Received : April 2, 2020 •Revised : April 20, 2020 •Accepted : April 24, 2020

- Address for reprints : Jae Taek Hong

Department of Neurosurgery, Eunpyeong St. Mary's Hospital, The Catholic University of Korea, 1021 Tongil-ro, Eunpyeong-gu, Seoul 03312, Korea

Tel : +82-2-2030-2505, Fax : +82-2-2030-2513, E-mail : jatagi@daum.net, ORCID : https://orcid.org/0000-0001-6453-0439

This is an Open Access article distributed under the terms of the Creative Commons Attribution Non-Commercial License (http://creativecommons.org/licenses/by-nc/4.0) which permits unrestricted non-commercial use, distribution, and reproduction in any medium, provided the original work is properly cited. 


\section{INTRODUCTION}

Cancer incidences are expected to increase, and overall survival of cancer is expected to decrease due to improved systemic therapy ${ }^{36)}$. As a result, the incidence of patients with spinal metastases will increase as will the complexity of management ${ }^{36)}$. Moreover, the median survival time of patients with bone metastases has substantially improved over the last decades, mostly because of advances in oncological treatment options ${ }^{35)}$. Because the presence of spinal metastases represents advanced cancer, the goal of treatment shifts from long-term survival to preservation of quality of life for the patient's remaining lifetime by retaining function and relieving symptoms ${ }^{22,35)}$.

In the past, external beam radiotherapy had been the cornerstone of treatment for painful spinal metastases ${ }^{35)}$. Since the study of Patchell et al. ${ }^{26)}$ in 2005, direct surgical decompression and stabilization in patients with metastatic epidural spinal cord compression has been feasible and demonstrated better outcomes ${ }^{14,18,25,38)}$. As surgical outcomes have been enhanced, consultations for surgery have increased to include spinal metastasis ${ }^{25}$. Skeletal-related events such as pathologic fracture after radiotherapy for spine metastases have a substantial negative impact on quality of life and daily functioning $^{35)}$. Although advancements in adjunct therapies have offered more treatment options, instability from spinal metastasis remains an important indication for surgical intervention $^{24,27)}$.

The Tomita and Tokuhashi scores were well-known scoring systems to help determine surgical treatments for spinal metastasis. However, their accuracy was limited, and they were regarded to be difficult for non-surgeons to use ${ }^{17,24)}$. For the nonsurgeon, difficulty in diagnosing spinal instability can lead to inappropriate referrals of patients without instability or undertreatment of patients with instability ${ }^{24)}$. Therefore, the Spinal Instability Neoplastic Score (SINS) was developed by the Spine Oncology Study Group (SOSG) to help physicians assess and categorize spinal instability; facilitate communication and appropriate referrals between oncologists, radiologists, and spine surgeons; and ensure that prompt and appropriate treatment plans can be developed as shown in Table $1^{10,24)}$.

Previous studies have shown that the SINS has a substantial to excellent interobserver and intraobserver reliability ${ }^{3,4,8,31)}$. However, the SINS has been evaluated by its authors and still requires independent validation before its wide clinical use ${ }^{4)}$.
Moreover, some studies reported that the total SINS score was not predictive for new or progressive vertebral compression fractures (VCFs) in patients receiving high-dose stereotactic radiotherapy ${ }^{6,28,30)}$. Therefore, the role of SINS has been debatable.

The purpose of this study is to delineate the accuracy and precision of the total and individual components of the SINS system for spinal instability to predict VCF.

\section{MATERIALS AND METHODS}

\section{Search strategy and study selection criteria}

In accordance with the Preferred Reporting Items for Sys-

Table 1. Spinal Instability Neoplastic Score (SINS)

\begin{tabular}{|c|c|}
\hline SINS component & Score \\
\hline \multicolumn{2}{|l|}{ Location } \\
\hline Junctional (occiput-C2, C7-T2, T11-L1, L5-S1) & 3 \\
\hline Mobile segment (C3-C6, L2-L4) & 2 \\
\hline Semirigid (T3-T10) & 1 \\
\hline Rigid (S2-S5) & 0 \\
\hline \multicolumn{2}{|l|}{ Pain } \\
\hline Yes & 3 \\
\hline Occasional pain but not mechanical & 1 \\
\hline Pain-free lesion & 0 \\
\hline \multicolumn{2}{|l|}{ Bone lesion } \\
\hline Lytic & 2 \\
\hline Mixed (lytic/blastic) & 1 \\
\hline Blastic & 0 \\
\hline \multicolumn{2}{|l|}{ Spinal alignment } \\
\hline Subluxation/translation & 4 \\
\hline De novo deformity (kyphosis/scoliosis) & 2 \\
\hline Normal alignment & 0 \\
\hline \multicolumn{2}{|l|}{ Body collapse } \\
\hline$>50 \%$ collapse & 3 \\
\hline$<50 \%$ collapse & 2 \\
\hline No collapse with $>50 \%$ body involved & 1 \\
\hline None of above & 0 \\
\hline \multicolumn{2}{|l|}{ Posterolateral involvement of spinal elements } \\
\hline Bilateral & 3 \\
\hline Unilateral & 1 \\
\hline None & 0 \\
\hline
\end{tabular}

Three categories ( 0 to 6 , stable; 7 to 12 , potentially unstable; and 13 to 18 , unstable) 
tematic Reviews and Meta-Analyses (PRISMA) guidelines, we conducted a systematic review of clinical studies that evaluated the SINS for spinal metastasis. A systematic search of PubMed, Embase, Web of Science, and the Cochrane Database was performed on the 30th of October 2019. The search term used was "Spinal Instability Neoplastic Score". There were no language restrictions on study eligibility, and only the largest study was included for overlapping study populations. In addition, the reference lists of the reviews were screened for qualifying studies. Search results were screened by scanning abstracts for the following exclusion criteria : case reports, letters, comments, reviews, or technical notes, animal studies, duplicate studies, usage of SINS for other disease, and metastatic spinal cord compression. After removing excluded ab-

Table 2. Levels of agreement for $\mathrm{K}$ statistic levels quoted by Landis and $\mathrm{Koch}^{16)}$

\begin{tabular}{lc}
\hline K value & Level of agreement \\
\hline $0.00-0.20$ & Slight \\
$0.21-0.40$ & Fair \\
$0.41-0.60$ & Moderate \\
$0.61-0.80$ & Substantial \\
$>0.80$ & Excellent \\
\hline
\end{tabular}

Three categories ( 0 to 6 , stable; 7 to 12 , potentially unstable; and 13 to 18 , unstable) stracts, full articles were obtained, and studies were thoroughly screened again using the same exclusion criteria. We excluded the following articles : no data of accuracy or precision or no prediction of VCFs. If data were missed in the included studies, we sent an e-mail to the corresponding authors of the papers to request data.

The goals of the search were to find articles that met the following inclusion criteria : comprised a group of spine metastases, included patients evaluated by the SINS after treatments such as radiation therapy or radiosurgery, and included data with accuracy or interobserver reliability of the SINS. Quality assessment was conducted independently in pairs and its consensus was reached by discussion. Study quality was determined for controlled observational cohort studies with the risk of bias assessment tool for nonrandomized studies (RoBANS).

Data were extracted from included studies according to two topics. One is accuracy of SINS. Evaluation tools for this were regression, uni-/multivariate analysis, or sensitivity/specificity. We analyzed accuracy of SINS category divided into two groups (SINS, 0-6 vs. 7-18) or three groups (SINS, 0-6 vs. $7-12$ vs. $13-18)$. We also evaluated accuracy of each component of the SINS (location, pain, bone lesion, radiologic alignment, body collapse, and posterolateral involvement) if data were available. The other topic was precision among evaluators. Interobserver reliability was commonly evaluated using

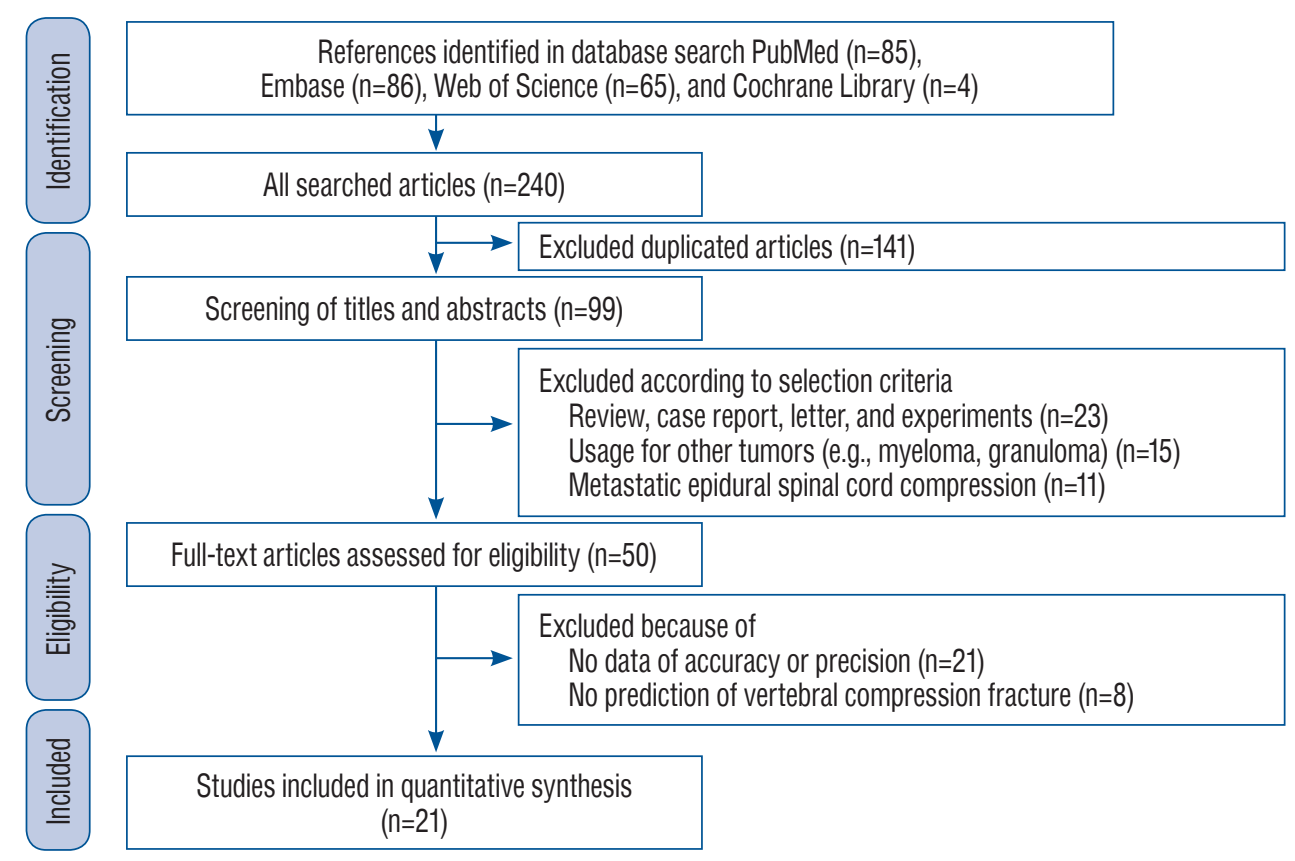

Fig. 1. Flow diagram outlining the process for selecting relevant studies. 
Cohen's kappa ( $\kappa$ ) value. We evaluated the reliability for the total score of the SINS and each component of the SINS. The $\kappa$ coefficients were interpreted according to the widely accepted Landis and $\mathrm{Koch}^{16)}$ grading system in Table 2.

\section{RESULTS}

\section{Search results for relevant studies}

An initial literature search using the subject headings iden- tified 85 studies in PubMed, 86 in Embase, 65 in Web of Science, and four in the Cochrane Central Register of Controlled Trials. Among these 240 studies, 141 were excluded as duplicates. Twenty-three of the 99 remaining papers were case reports, review articles, letters, technical notes, or patents and were excluded from our analysis. After screening the titles and abstracts, 15 studies that did not include metastatic spinal disease such as myeloma and granuloma and 11 that dealt with the metastatic epidural spinal cord compression. The 50 remaining studies were subjected to a full-text review, resulting

Table 3. Baseline characteristics of enrolled studies

\begin{tabular}{|c|c|c|c|c|c|c|c|}
\hline Study & $\begin{array}{l}\text { Study } \\
\text { region }\end{array}$ & $\begin{array}{l}\text { Primary cancer } \\
\text { (major organs) }\end{array}$ & $\begin{array}{l}\text { Mean age } \\
\text { (years) }\end{array}$ & Study period & $\begin{array}{l}\text { Mean follow- } \\
\text { up (months) }\end{array}$ & $\begin{array}{l}\text { Number of } \\
\text { patients }\end{array}$ & $\begin{array}{c}\text { Incidence of } \\
\text { event (\%) }\end{array}$ \\
\hline Cunha et al. ${ }^{6)}$ (2012) & Canada & Multiple (kidney, breast, lung) & $57.0 \pm 18.4$ & 2007 to 2011 & $7.4 \pm 9.4$ & $90(167)$ & 11.4 \\
\hline Sahgal et al. ${ }^{28)}$ (2013) & USA & Multiple (kidnry, breast, lung) & $57.6 \pm 18.4$ & N/D & $11.5 \pm 28.8$ & $252(410)$ & 13.9 \\
\hline $\begin{array}{l}\text { Sung and Chang } \\
\text { (2014) }\end{array}$ & Korea & Multiple (breast, lung, sarcoma) & $51.0 \pm 15.3$ & $N / D$ & $11.0 \pm 5.4$ & $72(72)$ & 36.1 \\
\hline Thibault et al. ${ }^{32)}$ (2014) & Canada & Renal cell cancer & $63.0 \pm 12.5$ & $\begin{array}{l}\text { October } 2007 \text { to } \\
\text { August } 2012\end{array}$ & $12.3 \pm 13.8$ & $37(61)$ & 16.4 \\
\hline Thibault et al. ${ }^{33)}$ (2015) & USA, Canada & Renal cell cancer & $60.2 \pm 13.9$ & N/D & $8.0 \pm 19.4$ & $116(187)$ & 18.2 \\
\hline Lam et al. ${ }^{15)}(2015)$ & USA & Multiple (breast, prostate, lung) & 62 & $\begin{array}{l}\text { January } 2008 \text { to } \\
\text { Decmeber } 2013\end{array}$ & N/D & 299 & 17.1 \\
\hline Aiba et al.' (2016) & Japan & NSCLC & 67 & 2009 to 2013 & $10.2 \pm 13.7$ & 47 & 31.9 \\
\hline Lee et al..$^{20)}(2016)$ & USA & $\begin{array}{l}\text { Multiple (kidney, breast, } \\
\text { thyroid) }\end{array}$ & $57.2 \pm 14.5$ & $\begin{array}{l}\text { March } 2004 \text { to } \\
\text { March } 2011\end{array}$ & 29.2 & 79 & 40.5 \\
\hline Germano et al. ${ }^{12)}(2016)$ & USA & Multiple (liver, breast, lung) & $62.0 \pm 11.0$ & $\begin{array}{l}\text { November } 2007 \\
\text { to January } 2014\end{array}$ & $16.0 \pm 18.0$ & $79(143)$ & 21.0 \\
\hline Virk et al. ${ }^{37)}$ (2017) & USA & $\begin{array}{c}\text { Multiple (renal, prostate, } \\
\text { sarcoma) }\end{array}$ & $60.7 \pm 4.6$ & 2005 to 2013 & $12.6 \pm 7.2$ & 323 & 8.0 \\
\hline Bollen et al..' (2017) & Netherland & Multiple (lung, breast, kidney) & $60.4 \pm 13.8$ & $\begin{array}{l}\text { January } 2000 \text { to } \\
\text { December } 2010\end{array}$ & $\mathrm{~N} / \mathrm{D}$ & 110 & 14.5 \\
\hline Shi et al. ${ }^{29)}$ (2018) & USA & Multiple (breast, lung) & $60.0 \pm 18.9$ & 2006 to 2013 & 5.9 & $203(250)$ & 20.4 \\
\hline Lee et al. ${ }^{19)}(2018)$ & Korea & Colorectal cancer & $61.0 \pm 10.7$ & $\begin{array}{l}\text { January } 2007 \text { to } \\
\text { December } 2014\end{array}$ & $10.0 \pm 24.5$ & $53(147)$ & 15.0 \\
\hline Chang et al. ${ }^{5)}$ (2018) & Korea & Multiple (breast, lung, liver) & $55.0 \pm 13.0$ & $\begin{array}{l}\text { January } 2008 \text { to } \\
\text { December } 2009\end{array}$ & 24 & 78 & 26.9 \\
\hline Fourney et al. ${ }^{10)}(2011)$ & World & N/D & $\mathrm{N} / \mathrm{D}$ & N/D & $\mathrm{N} / \mathrm{D}$ & 30 & N/D \\
\hline Teixeira et al. ${ }^{311}$ (2013) & Brazil & N/D & N/D & N/D & $\mathrm{N} / \mathrm{D}$ & 40 & N/D \\
\hline Campos et al. ${ }^{4)}$ (2014) & N/D & Multiple (kidney, breast, lung) & $65.0 \pm 14.3$ & $\begin{array}{l}\text { January } 2004 \text { to } \\
\text { March } 2011\end{array}$ & N/D & 30 & N/D \\
\hline Fisher et al. ${ }^{9)}$ (2014) & World & Multiple (lung, prostate, breast) & N/D & N/D & N/D & 30 & N/D \\
\hline Fisher et al. ${ }^{8)}$ (2014) & World & Multiple (lung, prostate, breast) & $\mathrm{N} / \mathrm{D}$ & N/D & N/D & 30 & N/D \\
\hline Arana et al. ${ }^{2)}$ (2016) & Spain & Multiple (breast, prostate, lung) & $N / D$ & N/D & $N / D$ & 90 & $\mathrm{~N} / \mathrm{D}$ \\
\hline Fox et al. ${ }^{11)}(2017)$ & Canada & N/D & N/D & N/D & N/D & 30 & $N / D$ \\
\hline
\end{tabular}

Values are presented as mean \pm standard deviation or number (segments). N/D : not described, NSCLC : non-small cell lung cancer 
in the exclusion of another 29 papers. The reasons for the exclusion of these articles consisted of the absence of data regarding accuracy or precision of SINS ( $\mathrm{n}=21)$ and no prediction of VCF ( $\mathrm{n}=8)$. Finally, a total of 21 studies were included in the meta-analysis. Detailed results of the selection process are shown in Fig. 1.

\section{Participant characteristics}

The characteristics of the included studies and participants are described in Table 3 . The 21 included studies investigated a total of 2118 patients and the countries in which the studies were conducted included worldwide $(n=3)$, United States $(n=7)$, Canada $(n=4)$, the Republic of Korea $(n=3)$, Brazil $(n=1)$, Japan $(n=1)$, Netherlands $(n=1)$, and Spain $(n=1)$. Among 13 studies that evaluated accuracy of the SINS, 11 studies analyzed the accuracy with which the SINS predicted VCF development, one study ${ }^{1)}$ evaluated skeletal-related events such as pathologic fracture, the need for surgery, bone radiation, spinal compression, and hypercalcemia; the other study ${ }^{5}$ assessed spinal adverse event (SAE) such as VCF, spinal cord compression, and a reduced quality of life. Ten studies estimated the incidence of VCFs after radiation therapy, two studies did it after stereotactic radiosurgery, and one studies did it after surgery. The aim and design of two studies by Thibault et al. ${ }^{32,33)}$ were overlap precisely, and differ only as the subjects have been expanded into multicenter. Therefore, we used data from the larger one.

\section{Accuracy of SINS to predict VCF}

Qualitative analysis of the accuracy of the SINS for estimating VCFs is demonstrated in Table 4. Among 13 studies, 11 studies agreed that the categories of the SINS described statistical significance in predicting VCFs. Eight studies reported accuracy of each item of the SINS ${ }^{3,5,6,12,19,28,29,33)}$. Six studies agreed that body collapse was effective in predicting VCFs. Four studies agreed that alignment and bone lesion were effective, and two supported that pain and posterolateral involve were effective. All eight studies showed that location has no statistical significance in predicting VCFs. A study ${ }^{3}$ reported that location was significantly associated with the cumulative incidence of an adverse event in the multivariate analysis. However, location was not significant in the univariate analysis, and the results indicated that a high-risk score indicates less risk of VCFs. Hence, the authors addressed that location might not provide any clinically relevant information when assessing spinal instability $y^{3)}$.

Table 4. Accuracy of SINS for estimating VCF

\begin{tabular}{|c|c|c|c|c|c|c|c|c|}
\hline Study & $\begin{array}{l}\text { Predicting } \\
\text { target }\end{array}$ & $\begin{array}{c}\text { Cat. of SINS } \\
\text { (number of Cat.) }\end{array}$ & Location & Pain & $\begin{array}{l}\text { Bone lesion } \\
\text { (lytic/blastic) }\end{array}$ & Alignment & $\begin{array}{l}\text { Body } \\
\text { collapse }\end{array}$ & $\begin{array}{c}\text { Posterolateral } \\
\text { involve }\end{array}$ \\
\hline Sung and Chang ${ }^{30)}(2014)$ & Post-SRS VCF & $\bigcirc(3, U)$ & & & & & & \\
\hline Lam et al. ${ }^{15)}(2015)$ & Post-RT SAE & $(2, U / M)$ & & & & & & \\
\hline Aiba et al.') (2016) & (Post-RT) SRE & $\bigcirc^{*}$ & & & & & & \\
\hline Lee et al. ${ }^{20)}(2016)$ & Post-RT VCF & $(2, U / M)$ & & & & & & \\
\hline Virk et al. $^{37)}$ (2017) & Post-SRS VCF & $\bigcirc^{*}$ & & & & & & \\
\hline Cunha et al. ${ }^{6)}$ (2012) & Post-RT VCF & $\bigcirc(2)$ & $x$ & $x$ & (U/M) & $\bigcirc(\mathrm{U} / \mathrm{M})$ & $\bigcirc(U)$ & $x$ \\
\hline Sahgal et al. ${ }^{28)}(2013)$ & Post-RT VCF & $\bigcirc(2)$ & $x$ & $x$ & $\bigcirc(\mathrm{U} / \mathrm{M})$ & $\bigcirc(\mathrm{U} / \mathrm{M})$ & $\bigcirc(\mathrm{U} / \mathrm{M})$ & $\bigcirc(U)$ \\
\hline Shi et al. ${ }^{29)}(2018)$ & Post-RT VCF & $(3, U / M)$ & $x$ & $\bigcirc(\mathrm{U} / \mathrm{M})$ & $\bigcirc(\mathrm{U} / \mathrm{M})$ & $\bigcirc(U)$ & $\bigcirc(U / M)$ & $\bigcirc(\mathrm{U} / \mathrm{M})$ \\
\hline Chang et al. (2018) & Post-Op VCF & $\bigcirc(3)$ & $x$ & $\bigcirc(\mathrm{U} / \mathrm{M})$ & X & $\bigcirc(\mathrm{U} / \mathrm{M})$ & $x$ & $x$ \\
\hline Lee et al. ${ }^{19)}(2018)$ & Post-RT VCF & (3) & $x$ & $x$ & 0 & $x$ & 0 & $x$ \\
\hline Thibault et al. ${ }^{33)}$ (2015) & Post-RT VCF & $\bigcirc(3, U)$ & $x$ & $x$ & $x$ & $x$ & $\bigcirc(\mathrm{U} / \mathrm{M})$ & $x$ \\
\hline Germano et al. ${ }^{12)}$ (2016) & Post-RT VCF & $x$ & $x$ & $x$ & $x$ & $x$ & $\bigcirc(U)$ & $x$ \\
\hline Bollen et al. ${ }^{3)}$ (2017) & Post-RT VCF & $x$ & $x$ & $x$ & $x$ & $x$ & $x$ & $x$ \\
\hline
\end{tabular}

*The probability of target events was correlated to total score of SINS. SINS : spinal instability neoplastic score, VCF : vertebral compression fracture, Cat. : category, SRS : stereotactic radiosurgery, U : results of univariate analysis (not multivariate analysis), RT : radiation therapy, SAE : spinal adverse event such as vertebral compression fracture, spinal cord compression, and reduced the quality of life, U/M : results of both univariate and multivariate analysis, SRE : skeletal-related events such as pathologic fracture, the need for surgery, bone radiation, spinal compression, and hypercalcemia, OP : operation 


\section{Precision of SINS to predict VCF}

Inter-observer reliability illustrated by the level of agreement and $\kappa$-values is demonstrated in Table 5. Eight studies evaluated the precision of the categories of the SINS; four studies reported excellent agreement; one, substantial; two, moderate; one, fair. Although there was a difference in the studies, the overall reliability of the SINS seems to be high. Among the six components of the SINS, the majority of the included studies reported that location showed near perfect agreement; body collapse, alignment, and posterolateral involvement showed moderate agreement; and bone lesion showed fair agreement. Regarding pain, the agreement of studies varied from moderate to excellent.

\section{DISCUSSION}

The SINS was known to show high accuracy and reliability and to help determine surgery to prevent post-radiotherapy VCFs for spinal metastasis. A qualitative assessment of the studies demonstrated certain consistencies regarding the SINS. The categories of the SINS demonstrated substantial accuracy and precision for predicting VCFs. Although a previous study insisted that the total score or each component of
SINS had a prognostic value for the occurrence of $\mathrm{VCFs}^{36)}$, our study concluded a different result. In terms of the accuracy of the six components of SINS, more than half of the studies reported that body collapse, bone lesion, and alignment were statistically significant as a predictor of VCF. All studies addressed that location has no statistical significance to predict VCF. In terms of precision, location demonstrated excellent reliability with high consistency of the included studies and bone lesion showed fair reliability. Some showed high accuracy and low precision and others showed low accuracy and high precision.

The SINS score is the sum of individual components of which some quantify the risk of spinal instability (e.g., location, bone lesion, posterolateral involvement) while other factors express the current degree of spinal instability (e.g., body collapse, alignment, pain) ${ }^{36)}$. The latter usually showed high accuracy to predict VCF and the former showed a low accuracy. In our review, body collapse was the most important component. Whereas, pain has little meaning. The pain of SINS described aggravated by movement, upright posture, or loading of the spine but relieved by recumbence (mechanical pain). However, this may be difficult to distinguish from non-mechanical back pain. Precision of components that express the current degree of spinal instability were usually relatively low.

Table 5. Precision of SINS for inter-rater reliability ( $\mathrm{k}$-value)

\begin{tabular}{|c|c|c|c|c|c|c|c|}
\hline Study & $\begin{array}{l}\text { Category of } \\
\text { SINS }\end{array}$ & Location & Pain & Bone lesion & Alignment & Body collapse & $\begin{array}{c}\text { Posterolateral } \\
\text { involve }\end{array}$ \\
\hline Arana et al. ${ }^{2)}$ (2016) & $\begin{array}{c}\text { Moderate } \\
(0.546)\end{array}$ & & & & & & \\
\hline Fisher et al.9. (2014) & $\begin{array}{l}\text { Excellent } \\
(0.83)\end{array}$ & $\begin{array}{l}\text { Excellent } \\
(0.94)\end{array}$ & $\begin{array}{c}\text { Substantial } \\
(0.73)\end{array}$ & $\begin{array}{l}\text { Substantial } \\
(0.65)\end{array}$ & $\begin{array}{c}\text { Moderate } \\
(0.49)\end{array}$ & $\begin{array}{l}\text { Substantial } \\
(0.61)\end{array}$ & $\begin{array}{c}\text { Moderate } \\
(0.55)\end{array}$ \\
\hline Fisher et al. ${ }^{8)}$ (2014) & $\begin{array}{c}\text { Excellent } \\
(0.80-0.85)^{*}\end{array}$ & $\begin{array}{c}\text { Excellent } \\
(0.94)\end{array}$ & $\begin{array}{c}\text { Excellent } \\
(0.88)\end{array}$ & $\begin{array}{c}\text { Moderate } \\
(0.55)\end{array}$ & $\begin{array}{c}\text { Moderate } \\
(0.42)\end{array}$ & $\begin{array}{c}\text { Moderate } \\
(0.57)\end{array}$ & $\begin{array}{c}\text { Moderate } \\
(0.43)\end{array}$ \\
\hline Campos et al. ${ }^{4)}$ (2014) & $\begin{array}{c}\text { Substantial } \\
(0.790)\end{array}$ & $\begin{array}{l}\text { Excellent } \\
(0.811)\end{array}$ & $\begin{array}{c}\text { Moderate } \\
(0.587)\end{array}$ & $\begin{array}{l}\text { Fair } \\
(0.210)\end{array}$ & $\begin{array}{l}\text { Moderate } \\
(0.453)\end{array}$ & $\begin{array}{c}\text { Moderate } \\
(0.421)\end{array}$ & $\begin{array}{l}\text { Fair } \\
(0.295)\end{array}$ \\
\hline Fox et al." (2017) & $\begin{array}{c}\text { Excellent } \\
(0.990)\end{array}$ & $\begin{array}{c}\text { Excellent } \\
(0.948)\end{array}$ & $\begin{array}{c}\text { Substantial } \\
(0.739)\end{array}$ & $\begin{array}{l}\text { Fair } \\
(0.382)\end{array}$ & $\begin{array}{c}\text { Moderate } \\
(0.427)\end{array}$ & $\begin{array}{c}\text { Moderate } \\
(0.550)\end{array}$ & $\begin{array}{c}\text { Moderate } \\
(0.435)\end{array}$ \\
\hline Fourney et al. ${ }^{10)}(2011)$ & $\begin{array}{c}\text { Excellent } \\
(0.846)\end{array}$ & $\begin{array}{l}\text { Substantial } \\
(0.790)\end{array}$ & $\begin{array}{c}\text { Excellent } \\
(0.841)\end{array}$ & $\begin{array}{l}\text { Fair } \\
(0.244)\end{array}$ & $\begin{array}{l}\text { Moderate } \\
(0.456)\end{array}$ & $\begin{array}{c}\text { Moderate } \\
(0.462)\end{array}$ & $\begin{array}{c}\text { Moderate } \\
(0.492)\end{array}$ \\
\hline Teixeira et al..11) (2013) & $\begin{array}{l}\text { Fair } \\
(0.375)\end{array}$ & $\begin{array}{l}\text { Substantial } \\
(0.719)\end{array}$ & $\begin{array}{c}\text { Moderate } \\
(0.419)\end{array}$ & $\begin{array}{l}\text { Fair } \\
(0.220)\end{array}$ & $\begin{array}{c}\text { Moderate } \\
(0.553)\end{array}$ & $\begin{array}{c}\text { Moderate } \\
(0.428)\end{array}$ & $\begin{array}{c}\text { Moderate } \\
(0.424)\end{array}$ \\
\hline Bollen et al. ${ }^{3)}$ (2017) & $\begin{array}{c}\text { Moderate } \\
(0.536)\end{array}$ & - & - & $\begin{array}{l}\text { Fair } \\
(0.299)\end{array}$ & $\begin{array}{c}\text { Fair } \\
(0.358)\end{array}$ & $\begin{array}{c}\text { Moderate } \\
(0.453)\end{array}$ & $\begin{array}{c}\text { Moderate } \\
(0.436)\end{array}$ \\
\hline
\end{tabular}

*The value was rate 0.85 by spine surgeons, and 0.80 by oncologists. SINS : spinal instability neoplastic score 
Body collapse and alignment demonstrated moderate interobserver reliability in six of seven studies. These components seem to be accurate and reliable. The precision of pain was quite heterogenous, and two studies showed moderate reliability among six studies; two showed substantial and two, excellent. The reason of the low accuracy of the pain may be the subjectivity in the assessment. The pain component needs to be defined more clearly. Sahgal et al. ${ }^{28)}$ reported that baseline body collapse, lytic tumor, and misalignment were predictive, whereas presence of pain, location, and posterolateral involvement of spinal elements were not.

Three components of the possible risk of spinal instability (e.g., location, bone lesion, posterolateral involvement) usually presented low accuracy and high reliability. Bone lesion showed significant accuracy in predicting VCFs in half of the studies, but displayed fair reliability in five of seven studies. Removing this component of the SINS might improve reliability, but would be detrimental to content validity. The SOSG addressed that the decision to include this category was made based on strong biomechanical literature suggesting that the cross-sectional area of a defect combined with bone mineral density are excellent predictors of vertebral body failure and pathologic fracture risk ${ }^{10)}$. To improve reliability, SOSG may consider using data with multi-slice computed tomography ${ }^{10)}$. As another possible risk, the location of a spine metastasis seemed to affect compression fractures that occur in mobile segments because of mechanical stress. However, location showed no correlation with VCFs in any of the studies. Even if the component displayed near perfect reliability, deleting or modifying the item needs to be considered.

The increasing incidence of spinal metastases has led to an increased need for surgical and radiotherapy interventions to maintain or improve patient-related quality of life. The SOSG recommends consultation with a spine surgeon for all patients with a SINS of 7 or greater ${ }^{7}$. After the application of the SINS in clinical practice, a change in the referral pattern might be expected with a decrease in inappropriate and/or late referrals $^{35)}$. This fact is important if one considers that one of the purposes of the SINS is to improve communication and coordination among physician from diverse disciplines dedicated to oncologic patient care, for instance, suggesting the need for surgical consultation $^{4}$. The future role of the SINS has yet to be determined. Ongoing research is required to continually update and validate each component and score to remain con- temporary to modern treatments and practices.

The SINS is developed to determine whether to perform surgery or radiation therapy depending on the risk of VCFs. To develop evidence-based treatment strategies for spinal neoplastic-related instability, it is important to use uniform definitions and outcome parameters ${ }^{36)}$. However, many papers used SINS to predict various target event for various tumors, which may make confusion of utility of SINS ${ }^{13,21,23,34)}$. We excluded papers regarding metastatic epidural compression, giant cell tumor, sarcoma, or myeloma, and papers estimating survival or re-treatment. VCF was known to be a fairly lowrisk adverse event after conventional radiotherapy, whereas a wide risk range estimates for VCF after spinal SSRS ${ }^{20)}$. Because the incidence of VCF affected the accuracy and precision, a clear definition of a target will be needed. Consistent use of the SINS and/or the components of the SINS to study spinal instability will facilitate uniform reporting of results and could ultimately enhance the quality of the research and patient outcomes.

\section{CONCLUSION}

The SINS system may be accurate and reliable in predicting the occurrence of post-radiotherapy or radiosurgery VCFs after spinal RT/SRS for spinal metastases. In terms of each component of the SINS, bony collapse, alignment, and bony lesion were accurate, but their precisions were fair to moderate. Location was high in reliability but low in accuracy. Diagnostic ability of location and bony lesion can have substantial weak points and need to be revised.

\section{CONFLICTS OF INTEREST}

No potential conflict of interest relevant to this article was reported.

\section{INFORMED CONSENT}

This type of study does not require informed consent. 


\section{AUTHOR CONTRIBUTIONS}

\author{
Conceptualization : JTH \\ Data curation : CHL \\ Formal analysis : CHL \\ Methodology : CHL \\ Project administration : JTH, SHK \\ Visualization : SHL, SY, MJS \\ Writing - original draft : CHL, JTH \\ Writing - review \& editing : CKC, SHK, MJS, SY, SHL, \\ $\mathrm{JTH}$
}

\section{ORCID}

Chang-Hyun Lee https:/orcid.org/0000-0003-0134-2101

Jae Taek Hong https://orcid.org/0000-0001-6453-0439

Sun-Ho Lee

https://orcid.org/0000-0003-3357-4329

Seong Yi

https://orcid.org/0000-0003-0700-4744

Moon-Jun Sohn https:/orcid.org/0000-0002-1796-766X

Sung Hwan Kim https:/orcid.org/0000-0002-0139-5003

Chun Kee Chung https://orcid.org/0000-0003-3485-2327

\section{References}

1. Aiba $H$, Kimura $T$, Yamagami $T$, Watanabe $N$, Sakurai $H$, Kimura $H$, et al. : Prediction of skeletal-related events in patients with non-small cell lung cancer. Support Care Cancer 24 : 3361-3367, 2016

2. Arana E, Kovacs FM, Royuela A, Asenjo B, Pérez-Ramírez Ú, Zamora J, et al. : Spine Instability Neoplastic Score: agreement across different medical and surgical specialties. Spine J 16 : 591-599, 2016

3. Bollen L, Groenen K, Pondaag W, van Rijswijk CSP, Fiocco M, Van der Linden YM, et al. : Clinical evaluation of the spinal instability neoplastic score in patients treated with radiotherapy for symptomatic spinal bone metastases. Spine (Phila Pa 1976) 42 : E956-E962, 2017

4. Campos M, Urrutia J, Zamora T, Román J, Canessa V, Borghero Y, et al. : The spine instability neoplastic score: an independent reliability and reproducibility analysis. Spine J 14 : 1466-1469, 2014

5. Chang SY, Ha JH, Seo SG, Chang BS, Lee CK, Kim H : Prognosis of single spinal metastatic tumors: predictive value of the spinal instability neoplastic score system for spinal adverse events. Asian Spine J 12 : 919 926, 2018

6. Cunha MV, Al-Omair A, Atenafu EG, Masucci GL, Letourneau D, Korol $\mathrm{R}$, et al. : Vertebral compression fracture (VCF) after spine stereotactic body radiation therapy (SBRT): analysis of predictive factors. Int J Radiat Oncol Biol Phys 84 : e343-e349, 2012
7. Fisher $\mathrm{CG}$, DiPaola $\mathrm{CP}$, Ryken $\mathrm{TC}$, Bilsky $\mathrm{MH}$, Shaffrey $\mathrm{Cl}$, Berven $\mathrm{SH}$, et al. : A novel classification system for spinal instability in neoplastic disease: an evidence-based approach and expert consensus from the Spine Oncology Study Group. Spine (Phila Pa 1976) 35 : E1221-E1229, 2010

8. Fisher CG, Schouten R, Versteeg AL, Boriani S, Varga PP, Rhines LD, et al. : Reliability of the Spinal Instability Neoplastic Score (SINS) among radiation oncologists: an assessment of instability secondary to spinal metastases. Radiat Oncol 9 : 69, 2014

9. Fisher CG, Versteeg AL, Schouten R, Boriani S, Varga PP, Rhines LD, et al. : Reliability of the spinal instability neoplastic scale among radiologists: an assessment of instability secondary to spinal metastases. AJR Am J Roentgenol 203 : 869-874, 2014

10. Fourney DR, Frangou EM, Ryken TC, Dipaola CP, Shaffrey Cl, Berven SH, et al. : Spinal instability neoplastic score: an analysis of reliability and validity from the spine oncology study group. J Clin Oncol 29 : 30723077, 2011

11. Fox S, Spiess M, Hnenny L, Fourney DR : Spinal Instability neoplastic score (SINS): reliability among spine fellows and resident physicians in orthopedic surgery and neurosurgery. Global Spine J 7 : 744-748, 2017

12. Germano IM, Carai A, Pawha P, Blacksburg S, Lo YC, Green S : Clinical outcome of vertebral compression fracture after single fraction spine radiosurgery for spinal metastases. Clin Exp Metastasis 33 : 143-149, 2016

13. Huisman $M$, van der Velden $J M$, van Vulpen $M$, van den Bosch MA, Chow $E$, Öner FC, et al. : Spinal instability as defined by the spinal instability neoplastic score is associated with radiotherapy failure in metastatic spinal disease. Spine J 14 : 2835-2840, 2014

14. Kumar N, Ravikumar N, Tan JYH, Akbary K, Patel RS, Kannan R : Current status of the use of salvaged blood in metastatic spine tumour surgery. Neurospine 15 : 206-215, 2018

15. Lam TC, Uno H, Krishnan M, Lutz S, Groff M, Cheney M, et al. : Adverse outcomes after palliative radiation therapy for uncomplicated spine metastases: role of spinal instability and single-fraction radiation therapy. Int J Radiat Oncol Biol Phys 93 : 373-381, 2015

16. Landis JR, Koch GG : The measurement of observer agreement for categorical data. Biometrics 33 : 159-174, 1977

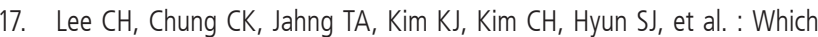
one is a valuable surrogate for predicting survival between Tomita and Tokuhashi scores in patients with spinal metastases? A meta-analysis for diagnostic test accuracy and individual participant data analysis. J Neurooncol 123 : 267-275, 2015

18. Lee $\mathrm{CH}$, Kwon JW, Lee J, Hyun SJ, Kim KJ, Jahng TA, et al. : Direct decompressive surgery followed by radiotherapy versus radiotherapy alone for metastatic epidural spinal cord compression: a meta-analysis. Spine (Phila Pa 1976) 39 : E587-E592, 2014

19. Lee J, Rhee WJ, Chang JS, Chang SK, Koom WS : Evaluation of predictive factors of vertebral compression fracture after conventional palliative radiotherapy for spinal metastasis from colorectal cancer. J Neurosurg Spine 28 : 333-340, 2018

20. Lee SH, Tatsui CE, Ghia AJ, Amini B, Li J, Zavarella SM, et al. : Can the 
spinal instability neoplastic score prior to spinal radiosurgery predict compression fractures following stereotactic spinal radiosurgery for metastatic spinal tumor?: a post hoc analysis of prospective phase II single-institution trials. J Neurooncol 126 : 509-517, 2016

21. Malhotra K, Lui DF, Butler JS, Selvadurai S, Molloy $S$ : Successful nonsurgical treatment for highly unstable fracture subluxation of the spine secondary to myeloma. Spine J 16 : e547-e551, 2016

22. Massaad E, Fatima N, Hadzipasic M, Alvarez-Breckenridge C, Shankar GM, Shin JH : Predictive analytics in spine oncology research: first steps, limitations, and future directions. Neurospine 16 : 669-677, 2019

23. Matsumoto Y, Shinoto M, Endo M, Setsu N, lida K, Fukushi Jl, et al. : Evaluation of risk factors for vertebral compression fracture after carbon-ion radiotherapy for primary spinal and paraspinal sarcoma. Biomed Res Int 2017 : 9467402, 2017

24. Murtaza $H$, Sullivan CW : Classifications in brief: the spinal instability neoplastic score. Clin Orthop Relat Res 477 : 2798-2803, 2019

25. Park JH, Lee DG, Hwang J, Lee SH, Eoh W, Kim ES : The impact of surgical treatment on survival in patients with cervical spine metastases. Neurospine 15 : 144-153, 2018

26. Patchell RA, Tibbs PA, Regine WF, Payne R, Saris $S$, Kryscio RJ, et al. : Direct decompressive surgical resection in the treatment of spinal cord compression caused by metastatic cancer: a randomised trial. Lancet 366 : 643-648, 2005

27. Ropper AE, Huang KT, Ho AL, Wong JM, Nalbach SV, Chi JH : Intraoperative cerebrospinal fluid leak in extradural spinal tumor surgery. Neurospine $15: 338-347,2018$

28. Sahgal A, Atenafu EG, Chao S, Al-Omair A, Boehling N, Balagamwala $E H$, et al. : Vertebral compression fracture after spine stereotactic body radiotherapy: a multi-institutional analysis with a focus on radiation dose and the spinal instability neoplastic score. J Clin Oncol 31 : 34263431, 2013

29. Shi DD, Hertan LM, Lam TC, Skamene S, Chi JH, Groff M, et al. : Assessing the utility of the spinal instability neoplastic score (SINS) to predict fracture after conventional radiation therapy (RT) for spinal metastases.

Pract Radiat Oncol 8 : e285-e294, 2018
30. Sung SH, Chang UK : Evaluation of risk factors for vertebral compression fracture after stereotactic radiosurgery in spinal tumor patients. Korean J Spine 11 : 103-108, 2014

31. Teixeira WG, Coutinho PR, Marchese LD, Narazaki DK, Cristante AF, Teixeira MJ, et al. : Interobserver agreement for the spine instability neoplastic score varies according to the experience of the evaluator. Clinics (Sao Paulo) 68 : 213-218, 2013

32. Thibault I, Al-Omair A, Masucci GL, Masson-Côté L, Lochray F, Korol R, et al. : Spine stereotactic body radiotherapy for renal cell cancer spinal metastases: analysis of outcomes and risk of vertebral compression fracture. J Neurosurg Spine 21 : 711-718, 2014

33. Thibault I, Atenafu EG, Chang E, Chao S, Ameen AO, Zhou S, et al. : Risk of vertebral compression fracture specific to osteolytic renal cell carcinoma spinal metastases after stereotactic body radiotherapy: a multiinstitutional study. J Radiosurg SBRT 3 : 297-305, 2015

34. Uei H, Tokuhashi Y, Maseda M, Nakahashi M, Sawada H, Matsumoto $K$, et al. : Clinical results of minimally invasive spine stabilization for the management of metastatic spinal tumors based on the epidural spinal cord compression scale. Biomed Res Int 2018 : 1258706, 2018

35. Versteeg $A L$, van der Velden JM, Verkooijen HM, van Vulpen $M$, Oner FC, Fisher CG, et al. : The effect of introducing the spinal instability neoplastic score in routine clinical practice for patients with spinal metastases. Oncologist 21 : 95-101, 2016

36. Versteeg AL, Verlaan JJ, Sahgal A, Mendel E, Quraishi NA, Fourney $D R$, et al. : The spinal instability neoplastic score: impact on oncologic decision-making. Spine (Phila Pa 1976) 41 Suppl 20 : S231-S237, 2016

37. Virk MS, Han JE, Reiner AS, McLaughlin LA, Sciubba DM, Lis E, et al. : Frequency of symptomatic vertebral body compression fractures requiring intervention following single-fraction stereotactic radiosurgery for spinal metastases. Neurosurg Focus 42 : E8, 2017

38. Weber MH, Burch S, Buckley J, Schmidt MH, Fehlings MG, Vrionis FD, et al. : Instability and impending instability of the thoracolumbar spine in patients with spinal metastases: a systematic review. Int J Oncol 38 : 5-12, 2011 